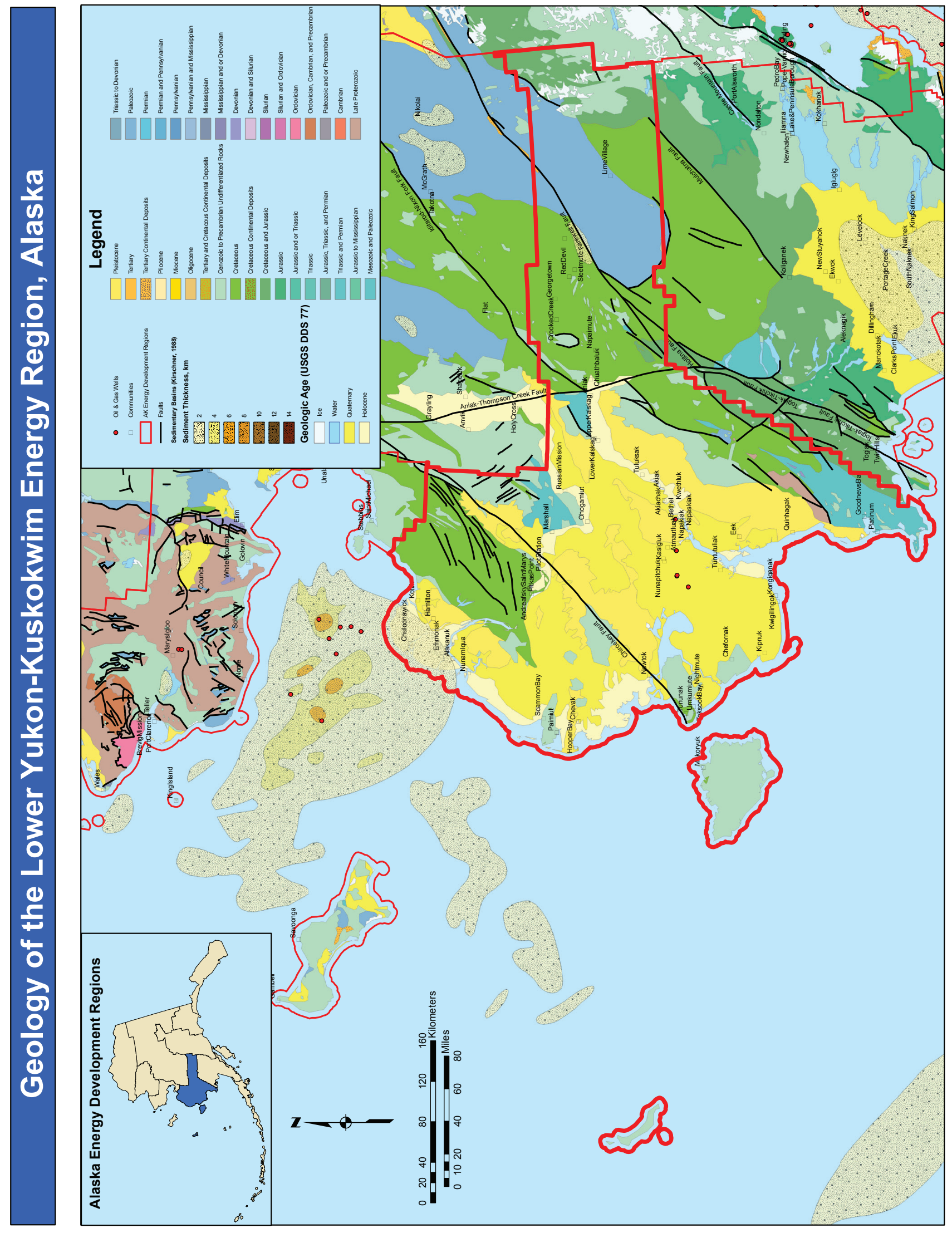





\section{SUMMARY OF FOSSIL FUEL AND GEOTHERMAL RESOURCE POTENTIAL IN THE LOWER YUKON-KUSKOKWIM ENERGY REGION}

by David L. LePain

\section{INTRODUCTION \\ Purpose of this report}

Economic growth and stability in Alaska's rural and urban areas hinges partially, if not primarily, on the availability of affordable and sustainable energy supplies. Recent price increases in oil and gas commodities have created severe economic hardship in many areas of the state that are dependent on diesel and heating oil as their primary source of energy. All sectors of Alaska's economy rely on affordable energy sources with limited price volatility, highlighting the need to diversify the energy portfolio by developing locally available and sustainable resources that are not tied to the global market. Unfortunately, all areas are not created equal in energy accessibility; the resources available for local exploitation vary widely across the state. It is critical that funding decisions for expensive programs to reduce the dependence on diesel for heat and electricity take into account information concerning the entire suite of natural resources that exist in a given area.

This report draws from existing information to provide community and state leaders an objective summary of our current knowledge concerning the potential of locally exploitable fossil fuel and geothermal energy resources in the Lower Yukon-Kuskokwim energy region (fig. G1), one of 11 regions recognized by the Alaska Energy Authority in their Energy Plan (AEA, 2009). The potential geologically hosted energy resources considered here include exploitable coal, conventional and unconventional oil and gas, and geothermal resources. This report concludes with recommendations as to what additional data or strategies, if any, would provide the most leveraging in helping to develop new energy resources in the region.

Readers without geological training are encouraged to peruse the geologic summaries of fossil fuel resources and geothermal energy in Chapter A. They provide an overview of the geologic elements that must be present in an area to economically develop coal, conventional oil and gas, unconventional oil and gas, and geothermal resources. These summaries will provide the necessary background to more fully understand the information presented in this chapter.

\section{Geographic and geologic setting}

The Lower Yukon-Kuskokwim Energy Region covers approximately 65,206 square miles in Southwest Alaska and extends from the east side of the Lime Hills Quadrangle, south of McGrath, to the Yukon-Kuskokwim delta at the western edge of the state (sheet 1). There is no road corridor from the Railbelt area and access to the region is limited to air and boat. The region's largest community is Bethel, located along the Kuskokwim River, with a current population of nearly 5,700. Other sizable communities include Hooper Bay, Mountain Village, and Aniak, with populations ranging from nearly 1,150 to slightly more than 500 residents. Many smaller villages are scattered widely throughout the region, and most of these are located in the vast Yukon-Kuskokwim

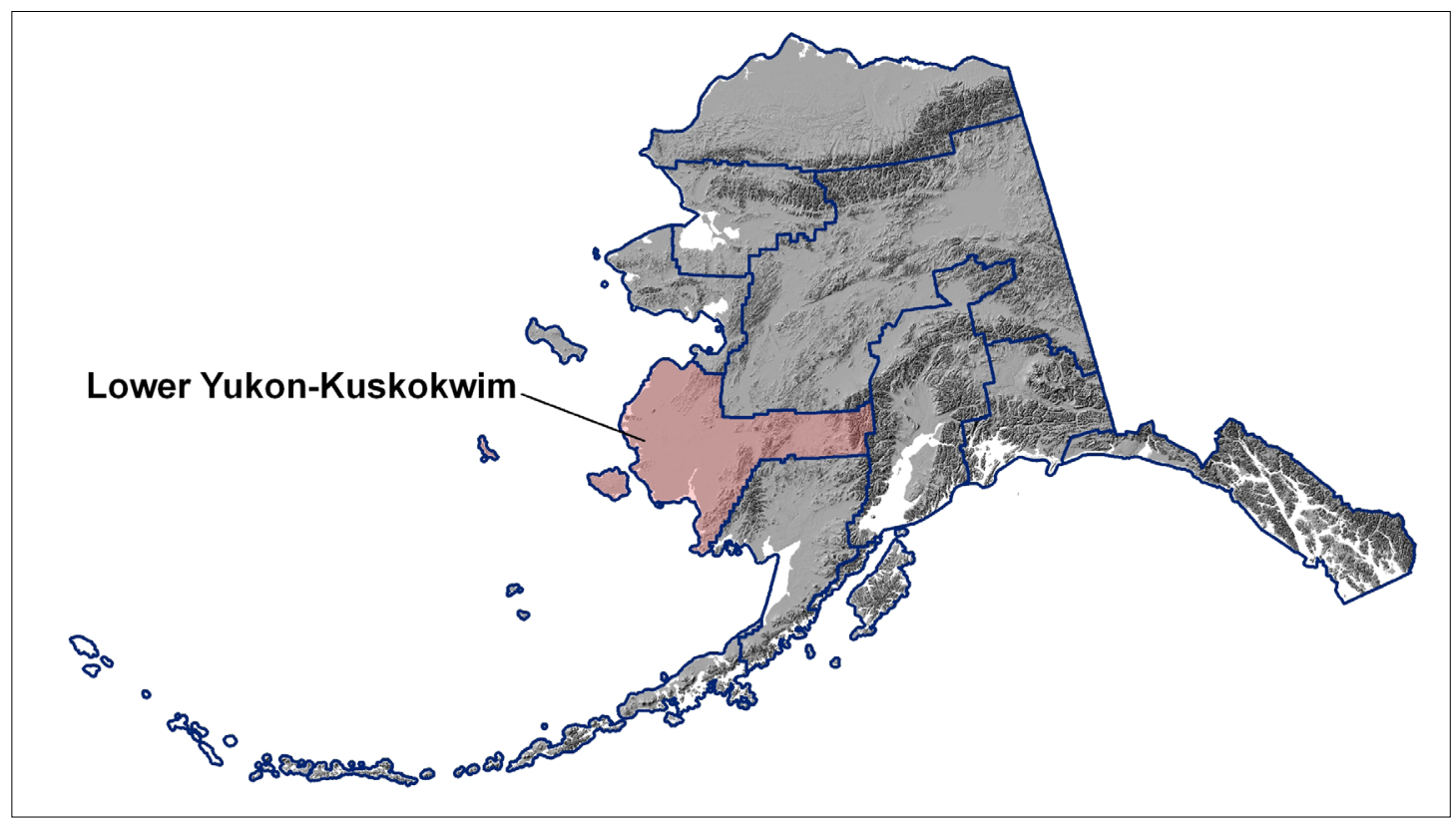

Figure G1. Location map of Lower Yukon-Kuskokwim Energy Region. 
coastal lowland. The region includes the Pribilof Islands, St. Matthew Island, and Nunivak Island - all located in the Bering Sea west of the Yukon-Kuskokwim lowland.

The region includes diverse topography, ranging from the steep, mountainous terrain of the southwestern Alaska Range at the far eastern end of the region, to rolling, hilly terrain represented by the Nushagak-Big River and Nulato Hills and the Ahklun and Kuskokwim mountains, to lowrelief lowland areas including the Holitna and Innoko lowlands and the broad flats of the Yukon-Kuskokwim coastal lowland (Wahrhaftig, 1965).

The high topography of the Alaska Range, which makes up the eastern end of the region, consists of intensely deformed (folded and faulted) Paleozoic- through Mesozoicage sedimentary rocks that represent uplifted pieces of former marine sedimentary basins (Nokleberg and others, 1994). West of these rocks the geology of the region consists of fault-bounded packages of Precambrian through Mesozoic sedimentary and volcanic rocks (Decker and others, 1994). The old Precambrian-age rocks represent a small crustal sliver of the crystalline foundation of North America that was probably transported to its present location in Southwest Alaska along crustal-scale strike-slip faults (Decker and others, 1994). The rest of the region consists of fragments of Paleozoic through early Mesozoic sedimentary basins and oceanic volcanic arcs that were deformed and accreted to North America over many tens of millions of years - a process that was largely completed by late Mesozoic time (approximately 90 million years ago; Patton and Box, 1989; Decker and others, 1994). A diverse collection of sedimentary and volcanic rocks characterize these basin fragments and include limestones, dolomites, sandstones, shales, bedded cherts, and volcanic-arc-related igneous rocks. Late Mesozoic-age (middle to Late Cretaceous age) sandstones and shales deposited in deep marine through coastal sedimentary environments accumulated in the YukonKoyukuk and Kuskokwim basins after accretion of the older sedimentary basins to North America (Patton and Box, 1989; Box and Elder, 1992).

Several major crustal-scale high-angle fault zones, including the Denali-Farewell, Iditarod-Nixon Fork, and Chiroskey faults, trend northeasterly across the region (sheet 2), and are largely responsible for the present-day distribution of these basin and volcanic arc fragments. The northeast-trending Tertiary-age Holitna basin (sheet 2) resulted from extension-related subsidence along the DenaliFarewell fault zone in the Sleetmute Quadrangle (Kirschner, 1994). Deformed Paleozoic and possibly Mesozoic rocks underlie this basin. The fill of this basin is poorly known, but is thought to include Cenozoic-age nonmarine sedimentary rocks similar to those exposed in the McGrath Quadrangle near Farewell (Kirschner, 1994; LePain and others, 2003). The shallow Bethel basin (sheet 2) is filled with up to 2,000 feet of Cenozoic-age nonmarine(?) sedimentary rocks that were deposited on deformed late Mesozoic-age sedimentary rocks similar to those recognized in the Yukon-Koyukuk and Kuskokwim basins (Kirschner, 1994; Mull and others, 1995). Numerous Cenozoic-age basaltic cinder cones and lava flows are present at the surface in the western part of the region (Kirschner, 1994).

The Norton basin, located in the northeastern Bering Sea (sheet 2), a short distance north of the modern Yukon delta and just beyond the northwestern boundary of the Lower Yukon-Kuskokwim region, formed because of strike-slip motion along the Kaltag fault zone and possibly east-west crustal extension (Fisher and others, 1981). Metamorphosed Precambrian-, Paleozoic-, and Mesozoicage rocks underlie the basin, which is filled with more than 20,000 feet of Tertiary marine and nonmarine sedimentary rocks (Turner and others, 1983). A prominent fault-bounded high comprising Mesozoic or older rocks trends north-south through the basin, splitting it into two sub-basins. The thick Tertiary successions in each sub-basin thin dramatically over this basement high (Fisher and others, 1981).

\section{GEOLOGIC ENERGY RESOURCE POTENTIAL IN THE LOWER YUKON- KUSKOKWIM ENERGY REGION Mineable coal resource potential}

Noteworthy occurrences of coal are known from only two areas - the Cheeneetnuk River and Nelson Island (figs G2 and G3). Both occurrences are relatively poorly understood, and available information is summarized below. Minor occurrences of coal are known elsewhere in the region, where they occur in nonmarine(?) deposits of the Kuskokwim Group. One such occurrence is along the North Fork of the Eek River and consists of several thin (few inches) coals and carbonaceous shales (Clough and others, in press). These occurrences are too thin to serve as viable energy resources for rural communities. At best, they might provide a heat source for a few remote cabins located nearby.

Cheeneetnuk River. Cenozoic-age coal-bearing sedimentary rocks are discontinuously exposed in a narrow belt that extends along the Alaska Range mountain front from at least the Little Tonzona River northeast of Farewell to the Cheeneetnuk River, southwest of White Mountain (fig. G2; Sloan and others, 1979; Bundtzen and Kline, 1986; LePain and others, 2003). W.H. Condon reported discontinuous exposures of coal-bearing rocks along a several-mile-long stretch of the Cheeneetnuk River, including one exposure with a 6-foot-thick seam of bright, brittle coal that appeared to be of bituminous rank, and suggested they occupied a downthrown fault block underlain by Paleozoic limestone (cited in Barnes, 1967, p. B21). Gilbert (1981) mapped these exposures in the McGrath A-5 and Lime Hills D-7 quadrangles (his map unit UTs) and noted that friable coal beds 1.6 to 16.5 feet thick occur in three places. Solie and Dickey (1982) present coal quality data for samples collected 


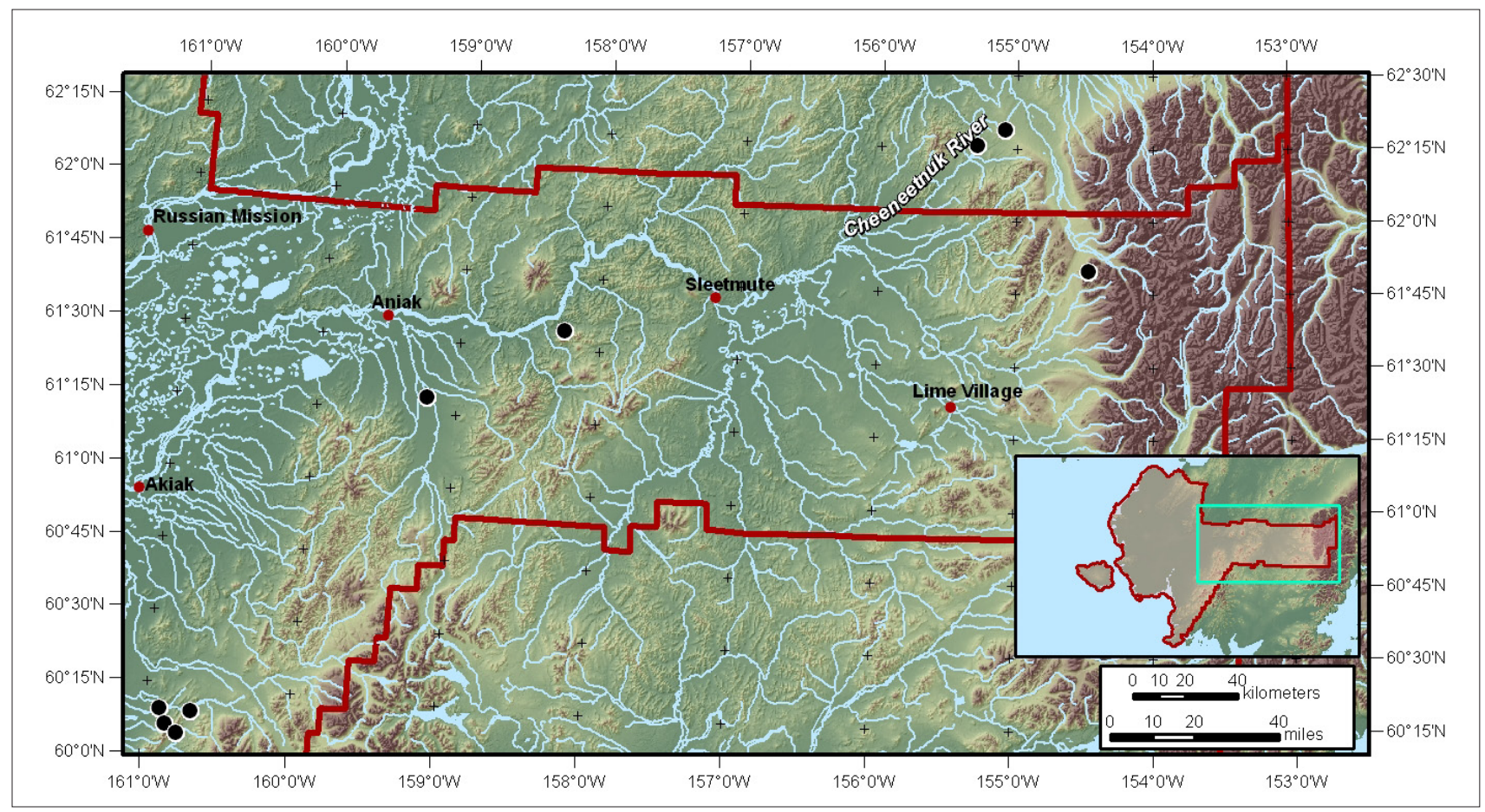

Figure G2. Location map of the eastern Lower Yukon-Kuskokwim Energy Region, showing selected geographic references noted in the text. Black dots indicate reported coal occurrences, particularly along the Cheeneetnuk River area.

by Gilbert from two of these locations (see their figure 5), including a 13- to 20-inch-thick bed and a 4- to 6-meterthick bed. They reported bed dips of up to 75 degrees, and that coal rank ranged from subbituminous B to high-volatile $\mathrm{C}$ bituminous. Ash content is low to moderate, and sulfur content ranges from high to very high (1.95 to 8.19 total sulfur on a moisture- and ash-free basis). The higher sulfur values suggest incorporation of interbedded ferruginous mudstone in the coal sample. LePain and others (2003) visited this area in 2000 and found low, overgrown exposures of mudstone along the north bank of the river, including coal float (small fragments), but were unable to locate exposures of coal. The presence of coal in this area is well established, but the number of seams, seam thickness, and lateral extent are unknown. Available information suggests that coal seams are of limited lateral extent and thickness, and thus likely do not represent a significant resource. Additional detailed geologic mapping and targeted shallow exploration (trenching and/or shallow drilling) would provide more detailed information that could alter this conclusion, but the absence of nearby communities makes additional work hard to justify (Sleetmute is more than 50 miles to the southwest and McGrath more than 60 miles to the north).

Nelson Island. Coal-bearing Cretaceous-age rocks crop out in coastal exposures on the west side of Nelson Island (fig. G3; Coonrad, 1957). Spurr (1900) reported coal from Nunivak Island (fig. G3) across Etolin Strait; no information is available for that coal occurrence, however, it appears to be a continuation of the nonmarine succession exposed on Nelson Island. The coal-bearing section on Nelson Island is part of a late-Mesozoic-age succession similar to that described by Patton and others (1994) in the Yukon-Koyukuk basin to the north. Clough and others (1994) measured and described a total of approximately 365 feet of nonmarine sedimentary rocks on this island and noted that coal accounted for less than 1.5 percent of this total. The thickest seam encountered was 19 inches, located east of the village of Toksook Bay. A coal sample from this section was submitted for laboratory analysis, which established its rank as medium-volatile bituminous, with ash content of 14.6 percent, and 0.5 percent sulfur (Clough and others, 1994). A 29-inch-thick bed of bituminous coal was reported on the north shore of the island at Hazen Bay, east of the village of Tununak (Spurr, 1900; Weber, 1944); however, this coal was covered by a thick snowbank and could not be evaluated in 1992 (Clough and others, 1994). Reportedly, a few tons of coal were mined from this locality but the years when this coal was mined are not known (Weber, 1944). Available data suggest coal from these seams represents a resource suitable for use by individuals to heat cabins. The lack of thick coal seams and uncertainty of the subsurface volume and extent of any coal suggests that coal has little potential for providing an energy source for local communities. 


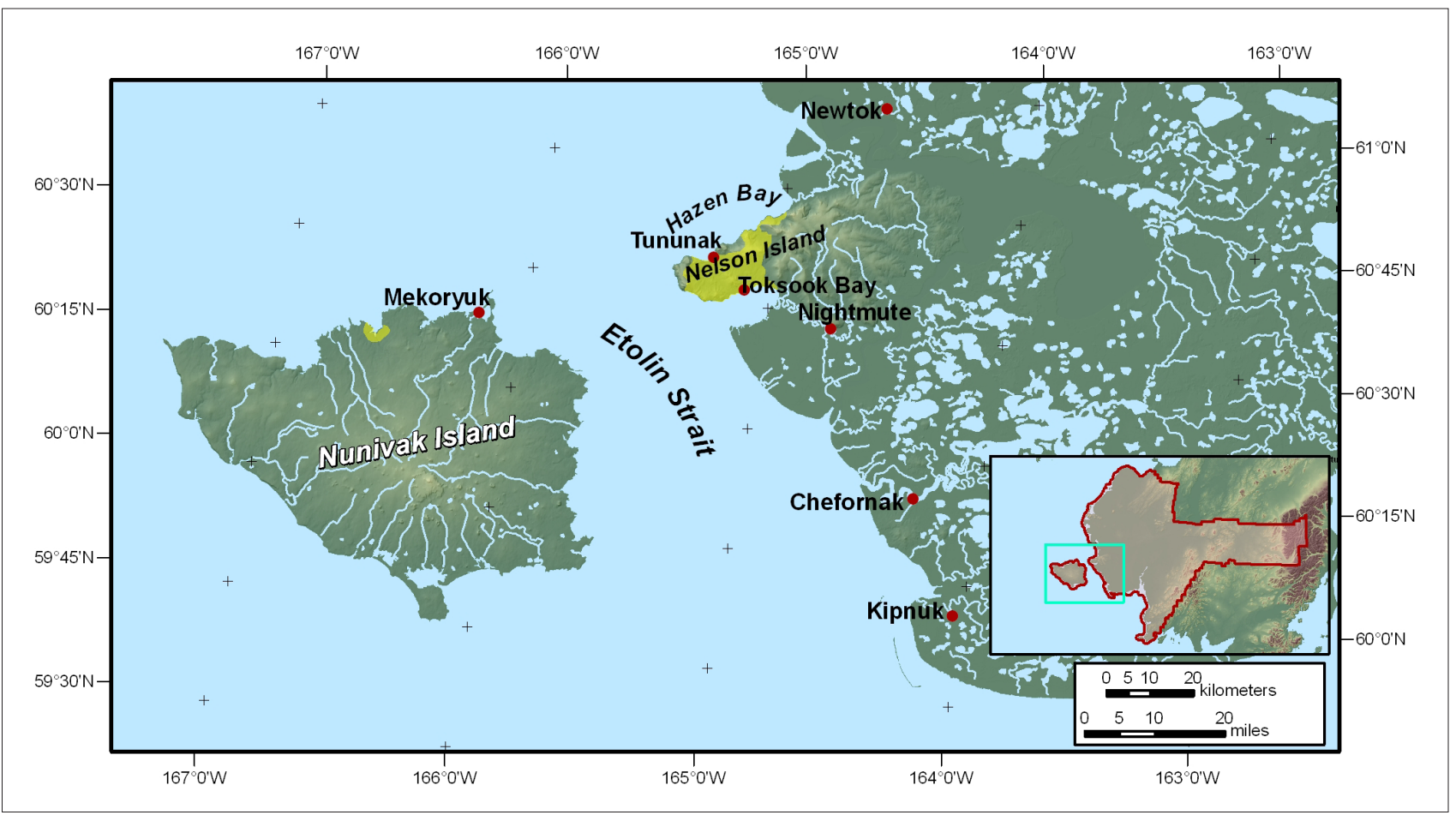

Figure G3. Location map of the western Lower Yukon-Kuskokwim Energy Region, showing reported coal occurrences (black dots) in the Nelson and Nunivak Island areas.

\section{Conventional oil and gas resource potential}

As explained in the discussion of requirements for exploitable oil and gas resources (see Chapter A), functioning petroleum systems occur in thick, sedimentary basins filled with thick successions of sedimentary rocks, and consist of three basic elements: Effective source rocks, reservoirs, and traps. Each of the elements must be in existence and connected at the time hydrocarbons are generated; if any one element is missing, a petroleum system is not present. This section considers each of the necessary elements of petroleum systems to evaluate whether conventional oil and gas resources may exist as an exploitable resource in the Lower Yukon-Kuskokwim Energy Region. The vast majority of the region is underlain by crystalline rocks and has no petroleum potential due to a geologic history of intense deformation, heating, and recrystallization under igneous and/or metamorphic conditions.

Overview of sedimentary basins. The distribution of sedimentary basins that could potentially host petroleum systems in the Lower Yukon-Kuskokwim region are shown on sheet 2. These include the Paleozoic-age Holitna basin, the Cretaceous-age Yukon-Koyukuk and Kuskokwim basins, and the Cenozoic-age Holitna and Bethel basins. The Paleozoic-age Holitna basin, to the northeast of the Kulukbuk fault, differs from the Cenozoic-age Holitna basin in age, size, and in the types of sedimentary rocks present. The Paleozoic Holitna basin is a fragment of a much larger sedimentary basin and is filled with deep marine through nearshore marine sedimentary rocks, including limestones, dolomites, sandstones, and shales. The Yukon-Koyukuk and Kuskokwim basins cover a large portion of the region, developed in Mesozoic time, and are filled with deep marine through nonmarine(?) strata (Nilsen, 1989). Late-Mesozoicage sandstones and shales, similar to those known from both the Yukon-Koyukuk and Kuskokwim basins, underlie a thin cover of Cenozoic-age strata throughout the Bethel basin (Kirschner, 1994; Mull and others, 1995), and most likely extend beneath a large part of the lower Yukon-Kuskokwim area, including the Yukon delta. The Cenozoic-age Holitna basin is a teardrop-shaped basin along the Denali-Farewell fault zone and gravity data suggest it is filled with nearly 15,000 feet of younger sedimentary rocks (sheet 2 ; Kirschner, 1994). Based on regional geology, the basin fill is assumed to be exclusively nonmarine, although the actual rock types in the subsurface are unknown owing to the absence of well data or rock outcrops in the footprint of the basin (LePain and others, 2000; 2003). The Cenozoic Bethel basin (sheet 2) is relatively thin, as indicated by the single exploration well that penetrated one of the deepest parts of the basin identified in gravity data (Mull and others, 1995).

The Yukon River has accreted a large delta where it has discharged into the Bering Sea over the last 12,000 to 15,000 years. Prior to this time, during the height of the last glacial episode, the delta was several hundred kilometers 
southwest of its present position, at the edge of the Bering Sea shelf. Hoare and Condon (1962) mapped surface sediments in the onshore portion of the modern delta and noted that unconsolidated deposits include silt, sand, gravel, and layers of brown peat up to several feet thick. They noted these deposits are many hundreds of feet thick. No deep wells have been drilled in the delta and details of the stratigraphy are known only from industry seismic lines. These data suggest a slightly thickened Tertiary succession underlies surficial deltaic sediment. The ancestral Yukon delta may have deposited sediment in the offshore Norton basin, located a short distance north of the modern delta, in the Federal outer continental shelf (OCS) area of the northeastern Bering Sea and Norton Sound. The Norton basin is an extensional basin filled with more than 20,000 feet of Tertiary-age marine and nonmarine sedimentary rocks (Fisher and others, 1981; Turner and others, 1983). Although outside of the Lower Yukon-Kuskokwim Energy Region, the Norton basin is included in the summary that follows.

Source rocks. Outcrop studies have documented that sedimentary rocks in the Paleozoic-age Holitna basin generally contain organic carbon in amounts less than what is generally regarded as a good petroleum source rock (LePain and others, 2000). Likewise, outcrop studies have documented that Cretaceous-age sedimentary rocks in the Yukon-Koyukuk and Kuskokwim basins generally contain organic carbon in amounts less than what is normally considered a good petroleum source rock, and the organic material that is present is typically gas-prone (Lyle and others, 1982). The Nulato Unit No. 1 well, in the western part of the Yukon-Koyukuk basin and outside of this region, penetrated 12,000 feet of deformed and tightly cemented Cretaceous-age sandstone, siltstone, and shale. No information is available on the organic content of shales encountered in this well, but the drilling reports (available from the Alaska Oil \& Gas Conservation Commission) suggest the siltstones and shales have poor petroleum source potential. The Napatuk Creek No. 1 well, approximately 50 miles southwest of Bethel, penetrated approximately 2,000 feet of Cenozoic-age rock and nearly 13,000 feet of interbedded sandstone, siltstone, and shale of Cretaceous age. The entire section penetrated by this well contains little organic material, and the material encountered was gas-prone (Mull and others, 1995).

The stratigraphy of the Cenozoic-age Holitna basin is not known and that of the Bethel basin is known only from a single exploration well (Napatuk Creek No. 1). Outcrop studies of Cenozoic-age sedimentary rocks along the DenaliFarewell fault zone in the McGrath Quadrangle by Sloan and others (1979), Dickey (1982), and LePain and others (2003) demonstrate the presence of coal and carbonaceous mudstone. These rocks are thought to be similar to the stratigraphy of the Cenozoic Holitna basin (LePain and others, 2003). Laboratory analysis of samples collected from the coal-bearing section in the McGrath Quadrangle (LePain and others, 2003) and of samples of similar-age rocks exposed in the Middle Tanana basin near Healy (Stanley and others, 1990) demonstrate their potential as source rocks for gas and also show some potential to generate liquid hydrocarbons (condensate) if buried deep enough. Gravity data suggests that the Holitna basin may locally contain nearly 15,000 feet of sediment in its deepest part (Kirschner, 1994). If the basin has a normal geothermal gradient, then any organic-rich sediment from the deeper parts of the basin could generate thermogenic hydrocarbons. Biogenic gas, generated by microbial processes, is often considered an unconventional resource due to its method of production in coalbed methane systems (see Chapter A). However, in some basins, such as the prolific Cook Inlet in southern Alaska, biogenic methane has been known to occur in conventional reservoirs. If thick coals are present in the Holitna Basin, it is reasonable to assume biogenic gas has been generated due to the microbial breakdown of buried organic matter. However, in order for biogenic gas to migrate into a conventional reservoir, an unusual set of geologic conditions are required involving the formation of early traps, rapid burial, and finally rapid uplift (Rice, 1993).

Details of the subsurface stratigraphy of the Yukon delta are poorly known. Hoare and Condon (1962) mapped the surface sediments in the delta, noted the presence of brown peat layers up to several feet thick, and stated the deltaic sediments are many hundreds of feet thick. Regional seismic data in the area suggest that a slightly thickened Tertiaryage succession may be present beneath the delta, but no information is available on the organic carbon content of these rocks and they are likely insufficiently thick to host a mature source rock (Mull and others, 1995).

Eight deep wells were drilled in the Norton basin in the early 1980s. Data from the COST No. 1 well are summarized in Turner and others (1983). Cuttings are typically organically lean (low percentage of organic carbon), except where contaminated by coaly material. Organic carbon is dominantly land-derived woody and herbaceous material. This type of carbon, when present in sufficient quantities at sufficient burial depths, typically generates gas. Geochemical data demonstrate sufficient temperatures and quantities of organic carbon beneath approximately 9,500 feet to generate conventional hydrocarbons. Of the eight deep wells drilled in the basin, all had moderate to strong gas shows and three had weak oil shows, demonstrating that rocks capable of generating hydrocarbons are present in the basin and have generated some petroleum. Thermally mature, organically lean strata of Eocene to middle Oligocene age are the most likely source rocks (Minerals Management Service [MMS], 1998).

Reservoir rocks. Partly dolomitized limestones in the Paleozoic Holitna basin commonly include visible porosity (LePain and others, 2000) and laboratory measurements demonstrate porosities greater than 10 percent in some 
samples of this lithology (Smith and others, 1985). It is reasonable to suggest that this rock type may also include sufficient permeability to function as a potential reservoir for petroleum. Most Cretaceous sandstones in the area are tightly cemented and have porosity and permeability below thresholds necessary for conventional oil and gas production (Lyle and others, 1982; Mull and others, 1995). Cenozoic sandstones exposed in the McGrath Quadrangle near Farewell appear tightly cemented, however, laboratory porosity and permeability measurements are not available. Similar age rocks exposed near White Mountain to the west appear loosely cemented and probably include significant porosity and permeability. Again, the stratigraphy of the Cenozoic Holitna basin is unknown. Consequently, it is unknown whether or not these tightly cemented and/ or loosely cemented sandstones are present in the basin. Sandstone is abundant in the offshore Norton basin and samples collected from the Norton Basin COST No. 1 well have average porosities well in excess of 10 percent. However, samples with porosities less than 24 percent tend to have low permeabilities (1 millidarcy or less; Turner and others, 1983), decreasing their potential as conventional hydrocarbon reservoirs.

Traps. The Paleozoic Holitna, Mesozoic YukonKoyukuk and Kuskokwim, and Cenozoic Holitna basins have all been subjected to one or more episodes of deformation (Decker and others, 1994; Patton and others, 1994; LePain and others, 2003). Complex folds and faults recognized in sedimentary rocks of the Paleozoic Holitna, Mesozoic Yukon-Koyukuk, and Mesozoic Kuskokwim basins suggest that potential structural traps for oil and gas are present in the subsurface of these basins. Complex folding and faulting of the Cenozoic section in the McGrath Quadrangle suggests similar deformation in the fill of the Cenozoic Holitna basin, providing potential for structural traps in that basin as well. Stratigraphic traps associated with pinch-outs of coarsegrained sandstones within shaley and silty horizons are also most likely present in the Mesozoic and Cenozoic basins. Trapping geometries formed by erosional truncation of sandstones beneath major erosion surfaces (unconformities) can also be expected. Low-permeability shales and siltstones are common in Cretaceous and Tertiary successions in the region and are probably capable of sealing hydrocarbons accumulated in traps. Seismic sections across the offshore Norton basin show ample evidence for potential structural and stratigraphic traps, including faulted anticlines and stratigraphic onlap above older basement rocks.

Summary of conventional oil and gas resource potential. After reviewing available data, LePain and others (2000) concluded the petroleum potential of the Paleozoic Holitna basin was very low due to the lack of suitable petroleum source rocks. Their conclusion is in general agreement with that of Smith and others (1985) from a study conducted in the early 1980s. Likewise, Mull and others
(1995) concluded the petroleum potential of the Bethel basin was low for similar reasons and this conclusion can safely be extrapolated to the portion of the Yukon-Koyukuk and Kuskokwim basins underlying the western part of the region. LePain and others (2003) evaluated the shallow gas potential (coalbed methane-unconventional gas) of the Cenozoic Holitna basin and concluded it was low due to the likely structural complexity of the basin fill. If coalbearing rocks are present in the Cenozoic Holitna basin at depths below approximately 5,000 feet, the basin could have some conventional gas potential and possibly some liquid hydrocarbon potential (condensate). The area comprising the deepest part of the basin is small and unlikely to support sizable petroleum accumulations. The next logical step in pursuing conventional hydrocarbons in the Cenozoic Holitna basin is to consider acquiring seismic data to image the subsurface structure and stratigraphy. Ultimately, one or more exploration wells will be required to test the conventional oil and gas potential of this basin.

The offshore Norton basin includes many of the elements necessary to have a functioning petroleum system. Geochemical samples collected from wells as deep as 9,500 feet in the Norton Sound COST No. 1 are rich enough in organic carbon and have been buried deeply enough to produce hydrocarbons and, in fact, gas shows were present in all eight deep wells drilled in the basin. An economic analysis by the U.S. Minerals Management Service (Reitmeier, 2005), which included numerous assumptions, concluded that an accumulation of at least 40 billion cubic feet of gas, if found within 40 miles of Nome, would be marginally capable of competing with diesel fuel at 2004 prices. Diesel prices are now higher and such a gas discovery would likely be more competitive. This analysis pertains to Nome only, where a sizable population is present and is relatively close to the basin. The many small communities scattered around the Lower Yukon-Kuskokwim Energy Region constitute a small and widely dispersed market that would likely render gas from a source in this basin non-economic for these communities. While Bethel and Aniak are sizable communities, they are most likely too far from the basin to justify exploration there to meet their energy needs alone.

\section{Unconventional oil and gas resource potential}

Coalbed methane. As explained in the discussion of requirements for coalbed methane, shalebed gas, and gas hydrates (see the appropriate summary reports for the requirements for these resource categories), several factors must be considered when evaluating whether a basin has unconventional oil and gas potential. Most importantly, suitable thicknesses of coal of the appropriate rank, or source rocks capable of generating gas must be present in a sedimentary basin. These rocks must then have a suitable geologic history in order to generate petroleum. 
LePain and others (2003) evaluated the shallow gas potential (coalbed methane-unconventional gas) of the Cenozoic Holitna basin and concluded the potential was low due to the likely structural complexity of the basin fill. As stated above regarding conventional oil and gas in the Cenozoic Holitna basin, no subsurface data are available from this basin and the next logical step in evaluating its conventional and unconventional petroleum potential is to acquire shallow seismic data and, pending results from these data, drill an exploration well (or wells).

Similarly, the subsurface stratigraphy beneath the modern Yukon delta is unknown. Seismic data suggest a slightly thickened Tertiary-age sedimentary succession, which could include unconventional gas accumulations. It is also possible that minor accumulations of biogenic gas are present in the shallow delta stratigraphy (Quaternaryage deposits). The sizes of these accumulations are likely to be very small, rendering their utility as energy sources marginal for even the smallest communities in the region. Assessing the coalbed methane potential of the deeper Tertiary stratigraphy will require one or more exploration wells, which require significant investment, with a relatively low chance of success.

Tight gas sands. As noted above, Cretaceous formations in the region typically lack sufficient porosity and permeability to function as conventional reservoirs for oil and gas and are correctly considered tight sandstone formations. However, the absence of suitable source rocks suggests these sandstones are not likely to have gas in their pore and fracture networks. Tight sandstones interbedded with coals and carbonaceous mudstones may be present in the subsurface of the Tertiary Holitna basin. Interbedded sandstones, coals, and carbonaceous mudstones are known from outcrops to the northeast in the McGrath Quadrangle (Dickey, 1982; LePain and others, 2003) and it is reasonable to infer their presence in the Holitna basin. Although the area of the Holitna basin is small, biogenic gas could have been locally generated from coals and migrated during uplift into tight reservoirs.

Available well data from the Norton basin suggest that tight gas sands could be present in the basin, particularly at depths greater than 6,000 feet, where compaction reduces porosity and permeability (Turner and others, 1986). Data from the two COST wells indicate that the deeper parts of the section are sufficiently mature to generate gas, although most of the sediments are low in total organic carbon (Turner and others, 1983a,b). Tight gas plays typically require closely spaced wells and artificial stimulation to be effectively produced; this type of unconventional resource would likely be challenging to economically develop in an offshore setting.

Shale gas. One of the primary requirements for shale gas is the presence of an organic-rich source rock present in the thermogenic gas window that is sufficiently brittle to host a natural fracture system (see Chapter A). For the same reasons outlined in the previous sections, the shale gas potential of
Paleozoic- and Cretaceous-age rocks in the region is very low due to the likely absence of suitable source rocks. For the same reasons cited in the discussion of coalbed methane potential, carbonaceous mudstones, if present in the Tertiary Holitna basin, are likely to be in structurally complex fault blocks, significantly reducing their potential as a shale gas resource.

Gas hydrates. The main occurrences of gas hydrates in nature are in modern marine sediments and in arctic regions with well-developed, continuous permafrost. Permafrost is not well developed in the Lower Yukon-Kuskokwim region and, where locally present, is discontinuous. Consequently, the potential for economic concentrations of gas hydrates in low.

\section{Geothermal resource potential}

Three hot springs are known in the Lower YukonKuskokwim region (sheet 2). These include Ophir, Chuilnuk, and an unnamed hot spring near the Tuluksak River $(\sim 5$ miles west of Ophir hot springs; Motyka and others, 1983). All three are known to be spatially associated with granitic plutons (Gassaway and Abramson, 1978). Measured water temperature at Ophir Hot springs is $142^{\circ} \mathrm{F}\left(61^{\circ} \mathrm{C}\right)$ and the flow rate is estimated at 71 gallons/minute. Measured water temperature at Chuilnuk is $124^{\circ} \mathrm{F}\left(51^{\circ} \mathrm{C}\right)$ and flow rate is estimated at 145 gallons/minute. Temperature and flow data are not available for the unnamed hot springs. Ophir and the unnamed hot springs are both approximately 15 miles north of Nyac and 25 miles southeast of Kalskag, and Chuilnuk Hot Springs is approximately 40 miles southwest of Sleetmute. Given these distances, these hot springs are unlikely to represent resources capable of providing energy to nearby communities. The low-grade nature of these hotsprings, combined with their remote locations, significantly reduces their potential as viable geothermal energy resources.

\section{RECOMMENDATIONS \\ Conventional oil and gas resource recommendations}

The petroleum industry has expressed interest in the Lower Yukon-Kuskokwim region several times since the 1960s, when the Napatuk Creek 1 well was drilled in the Bethel basin. Since completion of that dry hole, a loose grid of two-dimensional (2-D) seismic data was collected from the Yukon delta area and several industry field parties conducted surface geologic investigations in and around the Holitna Lowland. These activities added to the geologic knowledge base of the region, but did not lead to additional exploratory drilling. Available geologic data suggest that Cretaceousage sedimentary rocks in the region have low potential for conventional oil and gas due a lack of recognizable source rocks and sandstone characteristics that suggest poor reservoir potential. Sedimentary rocks in the Tertiary Holitna basin could include coal and carbonaceous mudstone 
capable of generating biogenic gas or even thermogenic gas and condensates in the deepest part of the basin. The area comprising the deepest part of the basin is small and unlikely to support sizable petroleum accumulations. Nonetheless, the State should encourage private-sector exploration of the Tertiary Holitna basin, as it is possible that a small, but locally significant, gas accumulation could be present.

Of the areas covered in this summary, the Norton basin, located a short distance north of the Yukon delta in the Bering Sea and just beyond the boundary of the Lower Yukon-Kuskokwim region, is the most prospective for conventional gas. The large capital costs associated with offshore exploration and the low chance of achieving the desired outcome, suggest this type of future work will be conducted by industry as part of a search for commercially viable accumulations. The discovery of an economic gas field could result in the availability of natural gas for local energy needs. Exploration risk could be reduced with the acquisition of modern three-dimensional (3-D) seismic data that can potentially directly image hydrocarbon accumulations.

\section{Geothermal resource recommendations}

The remote location of the Ophir and Chuilnuk hot springs limit their utility as potential sources of geothermal energy. However, the presence of shallow heat flow at these springs is a positive indication of a locally elevated geothermal gradient, allowing for the possibility of additional hidden geothermal resources elsewhere in the region. Exploring directly for these potential resources would be difficult and expensive. One option to assist in the identification of areas of higher potential would be to include evaluation of local and regional geothermal gradients during mineral resource exploration activities, such as airborne geophysical surveys and core drilling.

\section{Unconventional oil and gas resource recommendations}

Coalbed methane. Due to the limited stratigraphic and areal extent of coals along the Cheeneetnuk River and on Nelson Island, the volume of coal likely present in these areas is insufficient to generate commercial quantities of coalbed methane. Coal and carbonaceous mudstone may be present in the subsurface Tertiary Holitna basin, but no subsurface data are available that test this possibility. Nearby outcrops of coal-bearing strata along the Denali-Farewell fault zone in the McGrath Quadrangle are highly deformed. If a similarly deformed coal-bearing section is present in the subsurface Holitna basin, its coalbed methane potential could be limited by steeply-dipping beds and extreme compartmentalization into many small, fault-bounded blocks.

Tight gas sands. Due to the lack of potential gas source rocks, the tight gas sand potential of Cretaceous strata in the region is low. For reasons mentioned above, the tight gas sand potential of the Tertiary Bethel and Holitna basins is low. Any projects to evaluate tight gas sands in the region should only be undertaken in combination with a more comprehensive analysis of the biogenic and thermogenic gas potential in any of the area's sedimentary basins.

Shale gas. Due to the lack of extensively fractured source rocks present within the thermogenic gas window, the likelihood of finding commercial quantities of shale gas in the region is low, therefore no further action is recommended.

Gas hydrates. Due to the lack of extensive permafrost and absence of identified source rocks, the likelihood of finding gas hydrates in the region is very low and therefore no further action is recommended.

\section{Coal resource recommendations}

Available information suggests that coals in seams of mineable thickness are limited to a small area along the Cheeneetnuk River in the southwestern and northwestern McGrath and Lime Hills quadrangles, respectively. Available data also suggest that the lateral extent of seams in this area is limited. Additional geologic mapping combined with excavation of shallow test pits could alter this conclusion and represent the next logical step in exploring the possibility that mineable coal deposits are present in this area. This area's location far from rural communities does not currently justify this work. However, if mineral development were to occur nearer to these coals, then the resource may warrant additional evaluation as a local source of energy for a mine.

\section{REFERENCES CITED AND \\ SELECTED BIBLIOGRAPHY}

Barnes, F.F., 1967, Coal resources of Alaska: U.S. Geological Survey Bulletin 1242-B, p. B1-B36, 1 sheet, scale $1: 2,500,000$.

Box, S.E., and Elder, W.P., 1992, Depositional and biostratigraphic framework of the Upper Cretaceous Kuskokwim Group, southwestern Alaska, in Bradley, D.C., and Ford, A.B., eds., Geologic studies in Alaska by the U.S. Geological Survey, 1990: U.S. Geological Survey Bulletin 1999, p. 8-16.

Bundtzen, T.K., and Kline, J.T., 1986, Coal, peat, and geothermal potential of the Kuskokwim Area Plan: Alaska Division of Geological \& Geophysical Surveys Public Data File 86-88, 16 pages.

Clough, J.G., Blodgett, R.B., Clautice, K.H., Banet. A.C., Jr., and McAtee, J.A., in press, New Insights on Tertiary and Upper Cretaceous coals of Southeast and Southwest Alaska, Alaska Division of Geological \& Geophysical Surveys, Preliminary Interpretive Report.

Clough, J.G., Hickok, B.D., McAtee, J.A., and John, A., 1994, Coal occurrences on Nelson Island, Southwest Alaska, in Rao, P.D., and Walsh, D.E., eds., Focus on Alaska's Coal 1993: University of Alaska Fairbanks Mineral Industry Research Laboratory Report Number 94, p. 107-112. 
Coonrad, W.L., 1957, Geologic reconnaissance in the Yukon-Kuskokwim delta region, Alaska: U.S. Geological Survey Miscellaneous Investigations 223, 1 sheet, scale 1:500,000.

Decker, J., Bergman, S.C., Blodgett, R.B., Box, S.E., Bundtzen, T.K., Clough, J.G., Coonrad, W.L., Gilbert, W.G., Miller, M.L., Murphy, J.M., Robinson, M.S., and Wallace, W.K., 1994, Geology of southwestern Alaska, in Plafker, George, and Berg, H.C., eds., The Geology of Alaska: Boulder, Colorado, Geological Society of America, The Geology of North America, v. G-1, p. 285-310.

Dickey, D.B., 1982, Tertiary sedimentary rocks of the Farewell fault zone, McGrath Quadrangle, Alaska: Sedimentary Geology, v. 38, p. 443-463.

Fisher, M.A., Patton, W.W., Jr., and Holmes, M.L., 1981, Geology and petroleum potential of the Norton Basin area, Alaska: U.S. Geological Survey Open-File Report 81-1316, $51 \mathrm{p}$.

Gassaway, J.S., and Abramson, B.S., 1977, Map and table showing distribution of known thermal springs and selected igneous rocks in central Alaska: U.S. Geological Survey Open-File Report 77-168-H, 1 sheet, scale $1: 1,000,000$.

Gilbert, W.G., 1981, Preliminary geologic map and geochemical data, Cheeneetnuk River area, Alaska: Alaska Division of Geological \& Geophysical Surveys Alaska Open-File Report 153, 10 p., 2 sheets, scale 1:63,360.

Hoare, J.M., and Condon, W.H., 1962, Preliminary geologic map of lower Yukon-Norton Sound region, Alaska: U.S. Geological Survey Open-File Report 62-62, 1 sheet, scale 1:500,000.

Kirschner, C.E., 1994, Interior basins of Alaska, in Plafker, George, and Berg, H.C., eds., The Geology of Alaska: Boulder, Colorado, Geological Society of America, The Geology of North America, v. G-1, p. 469-493.

LePain, D.L., Blodgett, R.B., Clough, J.G., Ryherd, T.J., and Smith, T.N., 2000, Generalized stratigraphy and petroleum potential of the Holitna region, Southwest Alaska: Alaska Division of Geological \& Geophysical Surveys Preliminary Interpretive Report 2000-1, 34 p., 1 sheet.

LePain, D.L., Blodgett, R.B., and Clough, J.G., 2003, Sedimentology and hydrocarbon source rock potential of Miocene-Oligocene strata, McGrath Quadrangle-An outcrop analog for the Holitna Basin: Alaska Division of Geological \& Geophysical Surveys Preliminary Interpretive Report 2002-5, 75 p.

Lyle, W.M., Palmer, I.F., Jr., Bolm, J.G., and Flett, T.O., 1982, Hydrocarbon reservoir and source-rock characteristics from selected areas of southwestern Alaska: Alaska Division of Geological \& Geophysical Surveys Professional Report 77, 15 p., 7 sheets, scale 1 inch $=25$ feet.

Minerals Management Service (MMS), 1998, Undiscovered oil and gas resources, Alaska federal offshore: U.S.
Department of the Interior Minerals Management Service Alaska OCS Region.

Motyka, R.J., Moorman, M.A., and Liss, S.A., 1983, Geothermal resources of Alaska: Alaska Division of Geological \& Geophysical Surveys Miscellaneous Publication 8, 1 sheet, scale 1:2,500,000.

Mull, C.G., Bundtzen, T.K., and Reifenstuhl, R.R., 1995, Hydrocarbon potential of the Lower Kuskokwim River area, Yukon-Kuskokwim Delta, southwest Alaska: Alaska Division of Geological \& Geophysical Surveys Public Data File 95-28, 34 p.

Nilsen, T.H., 1989, Stratigraphy and sedimentology of the mid-Cretaceous deposits of the Yukon-Koyukuk basin, west-central Alaska: Journal of Geophysical ResearchSolid Earth, v. 94, no. B11, p. 15,925-15,940.

Nokleberg, W.J., Plafker, George, and Wilson, F.H., 1994, Geology of south-central Alaska, in Plafker, George, and Berg, H.C., eds., The Geology of Alaska: Boulder, Colorado, Geological Society of America, The Geology of North America, v. G-1, p. 311-366.

Patton, W.W., Jr., and Box, S.E., 1989, Tectonic setting of the Yukon-Koyukuk basin and its borderlands, western Alaska: Journal of Geophysical Research, v. 94, no. B11, p. $15,807-15,820$.

Patton, W.W., Jr., Box, S.E., Moll-Stalcup, E.J., and Miller, T.P., 1994, Geology of west-central Alaska, in Plafker, George, and Berg, H.C., eds., The Geology of Alaska: Boulder, Colorado, Geological Society of America, The Geology of North America, vol. G-1, p. 241-269.

Reitmeier, Cameron, 2005, Engineering and economic analysis of natural gas production in the North basin: http:// www.mms.gov/alaska/re/Natural_gas_Norton.pdf.

Rice, D.D., 1993, Biogenic gas-Controls, habitats, and resource potential, in Howell, D.G., ed., The Future of Energy Gases: U.S. Geological Survey Professional Paper 1570 , p. 583-606.

Sloan, E.G., Shearer, G.B., Eason, J.E., and Almquist, C.L., 1979, Reconnaissance survey for coal near Farewell, Alaska: U.S. Geological Survey Open-File Report 79410, 18 p., 4 sheets, scale 1:250,000.

Smith, T.N., Clough, J.G., Meyer, J.F., Blodgett, R.B., 1985, The petroleum potential and stratigraphy of the Holitna basin, Alaska: AAPG Bulletin, v. 69, no. 2, p. 308.

Solie, D.N., and Dickey, D.B., 1982, Coal occurrences and analyses, Farewell-White Mountain area: Alaska Division of Geological \& Geophysical Surveys Alaska Open-File Report 160, 20 p., 1 sheet, 1 inch $=20$ meters. Spurr, J.E, 1900, A reconnaissance of southwestern Alaska: U.S. Geological Survey 20th Annual Report, p. 31-264. Stanley, R.G., McLean, Hugh, and Pawlewicz, M.J., 1990, Petroleum source potential and thermal maturity of the Tertiary Usibelli Group of Suntrana, Alaska, in Dover, J.H., and Galloway, J.P., eds., Geologic studies in Alaska 
by the U.S. Geological Survey, 1989: U.S. Geological Survey Bulletin 1946, p. 65-76.

Turner, R.F., Bolm, J.G., McCarthy, C.M., Steffy, D.A., Lowry, Paul, and Flett, T.O., 1983a, Geological and operational summary, Norton Sound COST No. 1 well, Norton Sound, Alaska: U.S. Geological Survey Open-File Report 83-124, 164 p., 7 sheets.

Turner, R.F., Bolm, J.G., McCarthy, C.M., Steffy, D.A., Lowry, Paul, Flett, T.O., and Blunt, David, 1983b, Geological and operational summary, Norton Sound COST No. 2 well, Norton Sound, Alaska: U.S. Geological Survey Open-File Report 83-557, 154 p., 7 sheets.

Turner, R.F., Martin, G.C., Risley, D.E., Steffy, D.A., Flett, T.O., and Lynch, M.B., 1986, Geologic report for the Norton basin planning area, Bering Sea, Alaska: Anchorage, Alaska, United States Department of the Interior, Minerals Management Service, Alaska OCS Region, OCS Report MMS-86-0033, 179 p.

Wahrhaftig, Clyde, 1965, Physiographic divisions of Alaska: U.S. Geological Survey Professional Paper 482, 52 p., 6 sheets, scale 1:2,500,000.

Weber, B.S., 1944, Coal deposits, Nelson Island, western Alaska: U.S. Bureau of Mines Initial War Minerals Report, 15 p., 1 sheet. 